\title{
Dangerous corpses in Mexico's drug war
}

\author{
Regnar Kristensen
}

On 16 December 2009, 400 heavily armed soldiers from the Mexican marine forces entered an enclosed residential zone in the city of Cuernavaca to arrest the drug baron Beltrán Leyva, leader of the Mexican drug cartel of the same name. He was classified as the most violent drug cartel leader on the planet by the American Drug Enforcement Agency (DEA), and as an extremely dangerous enemy of the fatherland by the Mexican president, Felipe Calderón. For several hours, the marines were engaged in heavy shooting with the end result that Beltrán Leyva was killed, along with three of his hit men and one marine. The Mexican press generally considered this incident a success story of the Mexican government's harder law-enforcement measures in the current war on organised crime. My approach to this incident, however, is not to analyse the hypercomplex discourse on state, law enforcement and organised crime in Mexico. Rather, I will take this story as a departure point for exploring the governance of dead bodies, which starts where it ends for most scholars of political science and criminology. As the contributions to this volume show, the corpse is not always the end of the story. On the contrary, as we shall see, a corpse still holds the power to stir up more death.

The overall argument is that the brutal treatment of corpses transgresses the spheres of national security politics and the simple spread of terror. Corpses are instead seen as a social force that enchants politics and socialises religion. They make the past present 
and foresee possible futures. Drawing on popular Catholic practices I stumbled over in my fieldwork among criminal gangs in Mexico City, ${ }^{1}$ I take the liberty in this chapter of speculating on the possible social and cosmological complications of the violations of Beltrán Leyva's corpse in the Mexican drug war. The analysis takes it departure from the way in which Beltrán Leyva's corpse was dealt with and draws on theories of the sovereign's use of excessive force (Hansen and Stepputat 2005), the enchantment of politics (Verdery 1999) and the social lives of bones (Krmpotich et al. 2010). The conclusion is that a violent death in popular Catholicism may prevent the soul from leaving the dead body for purgatory, and that this provides the ground from which 'bone-trapped', restless spirits can terrorise the living.

\section{The story of Beltrán Leyva's corpse}

In the days after the killing of Beltrán Leyva, images of his corpse were broadcast in the Mexican and world media. The blood-covered corpse was shown with bullet holes and a disfigured arm. It was, moreover, stripped naked and covered with pesos and dollar bills soaked in his blood. On his stomach, somebody had placed several religious amulets and a paper slip with a number three on it, perhaps as a reminder of the custom in the Los Zetas drug cartel of naming members with a number. This cartel was, at that time, collaborating with that of Beltrán Leyva. The obscene photos of the disfigured, ridiculed corpse had not, however, received many comments in the media before the next instance of bloodshed occurred one week later, to which I shall return after following the corpse of Beltrán Leyva to his grave.

The burial of Beltrán Leyva's corpse was deferred for four days since there were a number of formalities to be undergone before it could be taken to the cemetery. Conspiracy pervades Mexico, and rumour had it that the corpse did not really belong to him. It was hence important for the Mexican government to prove that they had shot the right person. Beltrán Leyva's dead body therefore first had to be transferred to the forensic laboratory (SEMEFO) in Morelos in order for its DNA to be compared with a sample from his brother, who had served time in gaol, and confirm that the corpse was indeed Leyva's. The transfer of his corpse from the place of killing to the forensic laboratory was followed meticulously in most newspapers, from which I quote El Reforma: 
Elements of the marines started to mobilise inside and outside the residence before the removal of the corpse of Beltrán Leyva. The presence of elements from the marine force increased in the zone, in addition to the arrival shortly before of armed vehicles from the Mexican Army, which had to protect the area. ${ }^{2}$

To my initial surprise, it apparently required many heavily armed soldiers to transfer the corpse to the forensic laboratory. Equally surprising was the subsequent armed protection of the corpse at the forensic laboratory, which was also followed closely by all national newspapers. Quoting from El Universal:

The installations of SEMAFO were converted into an invincible fortress guarded by armoured cars, soldiers, tanks and artillery to avoid any incidents. Nobody was allowed to enter until the day after, when the sister of the deceased drug cartel leader and a friend of hers arrived and identified themselves at the entrance to SEMAFO. Immediately, the soldiers took positions of protection and sent a signal of alert to the police and soldiers surrounding the installation. ${ }^{3}$

My question here is why were the newspapers so eagerly describing the tense, secret and apparently very dangerous atmosphere around the forensic laboratory, which was converted into 'an invincible fortress'? The corpse subsequently had to be transferred to Culiacán, Beltrán Leyva's hometown in the state of Sinaloa. The media was again thrilled by this transfer. One newspaper stated that the corpse had been transferred from the Federal District to Culiacán (approximately 1,000 kilometres) in a large car followed by two military vehicles. ${ }^{4}$ Another, that a commercial aircraft had been hired to transfer it. ${ }^{5}$ The funeral itself was apparently also a major security challenge for the military. Quoting again from El Reforma:

Five army vehicles yesterday protected the convoy of ten cars which transferred the body of Beltrán Leyva to the graveyard of Jardines de Humaya, where he was buried in the presence of family and friends, mostly women and children. More than 150 soldiers blocked the main roads to the cemetery in a strong and vigilant operation. Women and children were astonished and terrorised at being checked by the soldiers, who stood outside the graveyard for sixteen hours to avoid any possible attack. Additionally, some soldiers were dressed in civilian clothes to oversee the cemetery from the inside. ${ }^{6}$

One might think this was the last we would hear of the corpse of Beltrán Leyva and yet, one month later, a brief notice in the national newspaper, El Universal, ${ }^{7}$ was soon reposted on various Internet pages such as Twitter and Latin News. It concerned an unpleasant 
incident of a decapitated head found on top of Beltrán Leyva's grave, apparently belonging to the corpse of a local resident who had been murdered and beheaded days before. Curiously enough some of the commentaries stated that the decapitated head might have been used in a satanic rite. ${ }^{8}$ This disfigured head was merely one more contribution to the gloomy Mexican statistic of a beheading a day among the fighting cartels in Mexico's drug war. In this case, the unfortunate person's head once again drew media attention to the disfigured corpse of Beltrán Leyva.

\section{The story of the marine's corpse}

Two days after Beltrán Leyva’s funeral, the marine who had been shot during the campaign was buried in the presence of both family and military personnel in his home state of Tabasco. Prominent soldiers and family accompanied his body on the last stretch of an official burial ceremony. The soldier's coffin was wrapped in the Mexican flag and followed to the grave while a band played the national anthem in the presence of the Secretary of the Marines. ${ }^{9}$ And yet the soldiers and Secretary of the Marines had barely parted with their dead colleague when the deceased's family was brutally gunned down on their way home. The dead marine's mother, brother, sister and aunt were all killed in a hail of bullets from the hitmen of the Los Zetas drug cartel. This bloodshed was interpreted by the media as revenge for the publication of the obscene photos of Beltrán Leyva's corpse. To quote one journalist: 'This rage is in response to the barbaric treatment of the corpse of Beltrán Leyva who, despite being a criminal, has the right to some dignity. ${ }^{10}$ The discussions in the media following the killing and counter-killings soon took on a political agenda. Whereas left-wing politicians and journalists attacked the barbarism of both the cartels and the government and depicted it as a clear sign of the government's loss of control and inability to protect its own citizens, the government's version was rather to downplay the importance of the photos, if not to attempt to apologise for their grotesque nature, saying it was a bad joke on the part of the forensic staff. ${ }^{11}$ Yet, at the same time, it claimed that the barbarically violent murders of the dead soldier's family were the irrational behaviour of criminal groups that were being squeezed into a corner in the current war on crime.

By now, it should be clear that the desecration of Beltrán Leyva's corpse had had violent consequences. The desecration of his corpse 
was clearly overstepping some moral boundary. Without doubt, many Mexicans fear the escalating rate of killings and disfiguration of corpses. Many of them welcomed this incident as an opportunity to criticise the government and the cartels for engaging in ever more 'uncivil warfare', in which violence does not follow normal codes of honour. Regardless of the side of the political spectrum, the violence against Beltrán Leyva's corpse and the deceased marine soldier's family was hence described as barbaric, uncivilised behaviour. In both cases, cultural and international practices of the proper conduct of 'war' were transgressed. However, although it could be seen as simple terror on the part of the Los Zetas drug cartel, there was no need for the forces of law and order to take those same means into their hands, even though they were perhaps not displeased with the effects of the published pictures. They showed a wider audience that the state can also transgress the normal boundaries of 'war' conduct to maintain the image of a sovereign state's far-reaching power. In this case, the excess of one seems to have triggered the excess of the other, indicating that we are currently witnessing a special economy of violence in Mexico analogous to economies of terror seen elsewhere (e.g. in Colombia; see Taussig 1987). The treatment of corpses is here vital for the excess to trigger further terror.

\section{Sovereign bodies and the will to violence}

Scholars have drawn attention to the fact that so-called 'wars' on internal enemies (e.g. criminals or terrorists) within nation-states take on characteristics which are different from those of traditional 'wars' between nations. They question, in particular, the notion of sovereign bodies by suggesting a shift in ground of our understanding of sovereignty from issues of territory and external recognition by states to issues of internal constitutions of sovereign power within states through the exercise of violence over bodies and populations (Hansen and Stepputat 2005: 2). Drawing on Foucault and Bataille, Hansen and Stepputat suggest that the heart of sovereignty can be found in the use of irrational, excessive and arbitrary power. Surplus power and excess is, for them, the very mark of sovereignty (2005: 11). It is not, however, an all-consuming power. On the contrary, as they also argue, '[S]overeignty is the tension between the will to arbitrary violence and the existence of bodies that can be killed but also resist sovereign power' (2005: 13). 
In Beltrán Leyva's case, it was not only the state that had the will to excessive violence. The drug cartel also had this will, and, as such, the case is an example of how an organised criminal group acts as an informal sovereign power that has become a law unto itself and, at the same time, the perennial outside, an unruly and original source of sovereign life that is a necessary condition for any claim to defend a social order. As Hansen and Stepputat argue: '[I]n such situations the state is not the natural and self-evident centre and origin of sovereignty, but one among several sovereign bodies that tries to assert itself upon the bodies of asylum seekers, "terrorist", or mere criminals' (2005: 36). However, if the irrational, uncivil violence is the force of the living sovereign powers (in this case both the cartels and the Mexican state), what of the apparent puzzle of the force of the dead corpse? I am here referring to the rather strange presence of so many soldiers in the last journeys of the corpse of Beltrán Leyva from his death to the cemetery in Culiacán five days later. The most violent cartel leader on the planet, to paraphrase the DEA, seemed peculiarly enough - to be more dangerous dead than alive. In the newspapers, the presence of soldiers was explained by the desire to 'protect' and 'avoid incidents' or 'attacks'. It is hard to believe, however, that the relatives or neighbours considered the presence of armed forces as protective; after all, it was soldiers that killed Beltrán Leyva. If anything, it was the corpse of the dead marine, or at least his family, that needed this protection. The fact that many might also have been tempted to take revenge on Beltrán Leyva's relatives for the violence he committed cannot be ruled out, yet the military presence still seems exaggerated, and, as seen with the deceased soldier, vengeance does not need the presence of the original corpse for it to be delivered.

It can also be argued that the state's interest in protecting the dead bodies is because they wished to influence the recognition of the dead person, in this case converting the dead soldier into a national hero and the dead drugs baron into a national tragedy. And yet, if the military presence was merely symbolic, it was counterproductive to allow so many soldiers to walk the 'evil' guy to his grave, making his funeral reminiscent of a state funeral. As Katherine Verdery has convincingly argued in The Political Lives of Dead Bodies (1999), there may be more enchanted approaches towards corpses than the sovereign's image strategies. She suggests here a different take on the politics of corpses by focusing on how the reburials of revolutionary leaders, artists and more humble folk have enchanted the political life of Eastern Europe and played a fundamental part in revising the past and reorienting the present following the fall of the Soviet 
Union. Her take on these complex symbolic processes is grounded in cultural anthropology, giving the negotiation of meaning precedence over explanatory models.

I present the politics of corpses as being less about legitimating new governments (though it can be that too) than about cosmologies and practices relating the living and the dead. And I see the rewriting of history that is obviously central to the dead-body politics as part of a larger process whereby fundamental changes are occurring in conceptions of time itself. (Verdery 1999: 26)

By 'changes in the conception of time', Verdery is referring to the ability of dead bodies to transcend time, making past human beings immediately present. It should be clarified that Verdery analyses reburials of corpses. Beltrán Leyva was not reburied but merely buried. Not much time passed between his death and his burial. Still, I find Verdery's take on corpses as reference points for a cultural enchantment of politics to be rewarding when exploring the immediate afterlife of Beltrán Leyva’s corpse. No matter what side we see it from, the burial of his corpse was part of a wider cultural context in which both the state and the cartel's reactions could be viewed and criticised for overstepping the proper cultural treatment of corpses, evidencing a lack of respect for both dead and living but also creating an enchanted environment of suspense as evidenced in the newspaper descriptions of the mystery and dangers surrounding Beltrán Leyva's last journey from Cuernavaca to the graveyard in Sinaloa. They expected something ugly to happen but did not know from where it would come, nor what form it would take. This suspense, underscored by the head subsequently found on his grave, is evidently embedded in cultural practices that look forwards as much as backwards, where time flows easily between past, present and future. The point of drawing on Verdery is that her view on political corpses underscores this ability to transgress the past and make it present, which in this case is a scary thought but also an 'enchanted' way of interpreting dead-body politics in Mexico. As Verdery cogently points out, dead bodies as a symbol have the great advantage of not talking much on their own, even though they did once (1999: 29), which makes them altogether unusually protean and concrete symbols (1999: 52). As she states:

They [corpses] are indisputably there, as our senses of sight, touch, and smell can confirm. As such, a body's materiality can be critical to its symbolic efficacy: unlike notions such as 'patriotism' or 'civil society', for instance, a corpse can be moved around, displayed, and strategically located in specific places. (Verdery 1999: 27; emphasis in the original) 
Hence, on the one hand we have these concrete, potent symbols that are moved around in the national geography, contributing to the political landscape of excessive violence. On the other, they make the past present and foreshadow the future in so far as they send a strong message to the public of what might happen. The word 'enchanted' captures here the ambivalent sensation of awe, thrill and being spellbound, and furthermore connects the dead bodies to the national history of violence, which could transgress to the present. The construction of the Mexican state has been narrated as an extremely violent one (Brandes 2006; Lomnitz 2005) with several beheadings and disfigurations of founding state heroes, Miguel Hidalgo, Santa Anna and Pancho Villa being just three of the most famous. The founding father of Mexican independence, Miguel Hidalgo, was publicly decapitated in 1811. The revolutionary hero Pancho Villa's skull was stolen from his grave in 1926 and the 'on and off' President Santa Anna lost his leg in a battle in 1838 and buried it in a graveyard in Mexico City, only to have it excavated and torn to pieces by an angry mob years later. If the cultural practices of corpses contain, as Verdery argues, the ability to transgress time, making past present, the treatment of these famous Mexican corpses becomes a frighteningly potent symbol. Seen as such, no wonder the brutal treatment of corpses generates such strong sensations among many Mexicans. Yet if the disfigured corpses are seen as violated 'lives' capable of transgressing time, would it also be possible to imagine that they have a more material life to them? Are they just particularly potent symbols, as Verdery argues, or is there some 'force' related to the materiality of these corpses? If this is the case, would it raise another more supernatural reason for the Mexican state and the soldiers to watch over the corpse of Beltrán Leyva? What if the forensic staff did desecrate his corpse for a joke and later made the military afraid of the cosmological consequences of their act? Or, to put it differently, what if the symbolic 'force' of his corpse, which shows his and his rivals' 'will to kill and be killed', was closely interlinked with the material life of the dead corpse?

\section{The substance of dead bodies}

To approach this line of investigation of the corpse's social life, I draw on some of the arguments discussed in the special issue on the material life of bones in the Journal of Material Culture (14(4), 2010). Some of the authors in the network are colloquially known 
as the 'Bones Collective'. They ground their investigations and theoretical approaches in distinguishing bones as things, and bones as substance. Quoting them:

In starting from this approach, we are not rendering bones as other-thanhuman, but rather focus attention on the very properties, processes and techniques through which bones and bone are constantly negotiated as person or things, subjects or objects, meaning or matter ... The approach we advocate here is a reading of bones (and indeed bodies) not predefined as corpse or as symbol but as parts of other people that are sensed through our faculties. (Krmpotich et al. 2010: 372)

Hence the question is not 'what do people do with bones?', as in Verdery's more symbolic approach, but rather 'what do bones do to people?'. In this approach, the scholars focus on the desire to find the individual subject in the bones. With the naming of the corpses comes an increased subjectivity and an increased humanness which counteract those aspects of mortuary practices that are often designed to distance the living and the dead, to transform the dead into another social space and set of social relations (Krmpotich et al. 2010: 379), in particular if the person suffered what Hertz long ago identified as a 'bad death' (1960), as in the case of both the soldier and Beltrán Leyva. Fontein and Harries have proposed that the humanising efforts might be a form of compensation for a 'bad death' (2009: 8). This compensation links otherwise qualitatively different worlds since the bones somehow connect past life (and violent death) with present violent afterlife. This opens up the possibility of inquiries into the religious experiences of the people in question. In the following, I will move the analysis into the field of religion, aware that popular Catholicism is a major player among both soldiers and criminals. It should be remembered that the obscene photos of the corpse showed religious amulets belonging to Beltrán Leyva placed on his mutilated body by the soldiers. Photos released after his death also showed figurines of the Virgin of Guadalupe and San Juan de Los Lagos standing on a shelf in his flat. My own research into criminal gangs in Mexico City that were associated with Beltrán Leyva also clearly demonstrated a strong religious devotion to popular Catholic saints and virgins among so-called criminals (Kristensen 2011).

Drawing on Fontein and Harries, the question is 'what do bones do to people' when they die violently? Popular Catholic beliefs in Mexico at times stress the fact that the souls of those dying 'badly' have a hard time leaving their earthly relatives. This was the case among the criminals I studied in Mexico City. They told me about 
how the lost souls of relatives or friends were troubling them or the people living physically close to the deceased (the graveyard, or where he or she had died). I was told that the souls of deceased relatives seek them out where they used to live (their home, place of death, former workplace, etc.). One family had severe problems with a son/brother/father who was killed by bodyguards when stealing to buy toys for Magic Day for his children. His soul was wandering restlessly, causing accidents (stove set on fire, things falling down scaring the children, etc.). Gang members also told me how one of them was violently attacked by a restless soul at Jubilete, a historical place on their pilgrimage from Mexico City to San Juan de Los Largos, where Catholics were killed by the Mexican Army in the Cristero War of 1926-9.

These attacks were explained by the deceased soul's incapacity to leave earth for a temporal purification in purgatory before the final judgement. In contrast to the souls of a 'good death' (Malvido 2005: 20-7), the souls of a 'bad death' stayed close to their bodily remains on earth and terrorised their living relatives and people passing close to their remains. The point I make here is not to explore further the public prayer sessions and rituals which families and pilgrims have ventured into to ensure that the deceased souls find peace and stop bothering them. I do not know what the family did to secure Beltrán Leyva's soul's peace of mind, if anything. The point is rather to speculate analytically as to whether the violent death of Beltrán Leyva and the disfiguration of his corpse could also have influenced how people view the afterlife of his soul. Before continuing with this analysis, I have to clarify that the idea of purgatory as a physical place is not part of the Roman Catholic Church's doctrine; however, gang members (and others) often believe that it is a place, as the noun grammatically indicates. This adds a spatial dimension to the purification process in purgatory, which becomes crucial to the 'lives' of the 'bone-trapped' souls who cannot leave earth because of their 'bad death'.

Extending the line of analysis of Fontein and Harries, I suggest Beltrán Leyva's disfigured bones not only 'do something to people' (trigger awe and violence) but also 'do something to his soul'. So far, we have seen that the soldiers followed the corpse closely for fear of new outbreaks of violence, and yet, given the popular Catholic beliefs in the roads afterlife can take, I cannot help speculating whether the disfigured bones might also contain a danger beyond this, in so far as they might oblige his soul to stay longer in the vicinity of his physical remains. On the one hand, the popular Roman Catholic belief 
has it that his death allows his soul to detach from his body and start a purification process in purgatory. Even for mortal sinners, there is a chance for salvation of their soul in purgatory, especially if the people left behind render sufficient worship to God and pray for them. For Roman Catholics it might, however, take a good deal of prayer before a soul is sufficiently purified; at least, there is no reason to believe that many Catholics in Mexico would not suspect this to be the case for this notorious violent drug baron. On the other, according to the popular belief mentioned earlier, his violent death and unfinished errands could prevent his soul from leaving earth, and this becomes a major cosmological problem if purgatory is somewhere other than earth. The result is a kind of long-term incomplete detachment of the soul from the dead body - which leaves the soul stranded in a long liminal period (see Turner 1967).

If we take popular Catholicism into consideration, Beltrán Leyva's last trip to the graveyard and beyond could thus also be seen as a stranded purification process whereby his soul is trapped near his dead body, leaving it restless to terrorise people, a scary thought when one considers his 'will to kill'. If we follow this line of speculative analysis a little further it brings us to the graveyards, since they are the physical place where living humans are closest to the 'bonetrapped', posthumous souls. What do these bones in the graveyards, then, do to people? How do living people approach and work with dead corpses?

\section{The 'force' of forgotten bones}

Work with dead bodies in Mexico is divided mainly between the Mexican state-owned cemeteries (there are also private cemeteries) and the dominant Catholic Church (there are also a number of other churches, e.g. Pentecostal, Methodist, Mormons, etc.). The Roman Catholic Church helps the souls in purgatory (by praying for them) and the state takes care of the dead bodies in the graveyards (by providing and maintaining the public burial grounds). There is no uniform Mexican approach to corpses, though, given that the secular Mexican state has been opposed to the Roman Catholic Church in Mexico per se ever since they were separated by President Benito Juarez in the middle of the nineteenth century. Still, the working division between state and Church has ensured that the two main players have had a fairly peaceful coexistence with regard to the 'governance of the dead', which stands in stark contrast to their disputes 
concerning 'the governance of the living' (e.g. abortion, divorce, etc.). The state does not interfere with how the Roman Catholic Church takes care of deceased souls at the time of death. Likewise the Roman Catholic Church does not interfere in the administration and caretaking of the bodies in the cemeteries, with the exception of the few church crypts that are open to new corpses. This does not mean that the one institution has no interest in the other's domain. As we saw in the above case of the dead soldier, there may be a mixture of national and religious symbols when burying a person.

Of the more than twenty cemeteries I visited in Mexico, it was not the presence of the living in the graveyards that caught my attention. Rather it was the oblivion of the dead bodies that came to my mind. Many graves were in a state of bad disrepair and, on some occasions, I would stumble over the bones of corpses because the graves had fallen apart and attracted dogs and other 'bone robbers'. The tradition of going to the cemetery seems less strong than the impression the vast literature concerning the practices of the Days of the Dead in Mexico might suggest (see Brandes 2006 for a similar point). This does not mean that the spirits of the deceased are forgotten; it just points to the fact that, in the popular Catholic faith, it is not necessary to visit relatives' material remains to retain a spiritual contact with the deceased and, I would like to add here, if they have had a good death (detachment). The famous celebration of the Days of the Dead on 1 and 2 November in Mexico consists, among other things, of setting up a family altar with photos of the deceased inside people's home, a popular tradition that is separate from the cemeteries. Those who venture into the cemeteries on these two nights every year (and many do), and who do not merely go to observe the others (which many also do), very likely go to visit their deceased relatives, as the tradition has it. The same tradition, however, also clearly tells that it is the souls of the dead that come back for a visit on the days named All Saints' Day and All Souls' Day rather than the bones, which are in the graveyard all year round. Indeed, for 363 days of the year, the souls are not believed to be together with their earthly bones, according to this tradition. So even in the best-known case of going to the cemetery in Mexico, these are the 'souls" days rather than the "bones" days.

The increasing use of cremation also illuminates this oblivion of the corpses. The Roman Catholic Church has traditionally discouraged people from using cremation, arguing that the body is a holy object through which the sacrament is received and, furthermore, that cremation constitutes a denial of the Christian belief in 
the resurrection of the body. During the nineteenth and twentieth centuries, cremation was hence viewed as pagan among Catholics, whereas the secular Mexican State had no problem with this practice. The Roman Catholic Church has, however, relaxed its policy towards dead bodies, and, in 1997, the Vatican granted an indult to allow for the celebration of the funeral liturgy, including mass, in the presence of the cremated remains, although this is still not preferred in most dioceses in Mexico. In spite of the clear differences between the state and the Catholic Church's 'governance of the dead' in Mexico, they therefore both seem to allow the corpses to slide into oblivion.

This oblivion of the corpses, however, results in a particular magical practice with bones. During my fieldwork in 2009-8, on several occasions I observed people looking for lonely, forgotten and unhappy corpses in the cemeteries. The idea was to take a lonely corpse home and seduce it to make it work for them (spying or killing). They had to persuade the dead body to do so by treating it well, smoking with it, serving it drinks and food and performing certain rituals. If no name was available on the tombstone, they would also name it. The dead body could refuse the invitation and would thus subsequently be returned to his or her grave. It was important that the dead person was very lonely (a badly kept grave) and that all the bones of the dead body could be collected to be sure that the spirit had all the bodily functions necessary to follow their orders (could hear, use its arms and legs, etc.), otherwise it would be of no use to send spying or killing. A 'fresh' corpse was considered to hold more power but was often not 'lonely' enough, making the seduction efforts harder. This may sound exotic and far removed from popular Catholic practices in Mexico, and so it is in many regards. The people participating in this moral economy explained the practice as drawing on aspects of Cuban Palo Monte (see Lydia Cabrera 1975) also known as Congo in Mexico City. There is some obvious African-Christian syncretism at stake (e.g. the use of Christian images in rituals) in this dealing with posthumous spirits. Still more significant for this analysis of the cosmological implications of what bones do to people and souls is the fact that those who 'kidnapped' the corpses from the cemeteries were the same people who went on long pilgrimages to Catholic shrines. They were devout Catholics, carrying a heavy cross while reciting popular prayers for their lost friends and relatives in purgatory. They feared attacks from restless souls, which they connected with the 'bad' deaths of the Cristero War or with people shot while stealing. The souls transgressed the 
past and became present when attacking the pilgrims, and the same transgression in time happened when the lonely bones were taken home from the cemetery to work for them. Whether dead souls or forgotten bones, they had the potential for a scary 'social life' in the present. In all cases, the cosmological order allowed for constellations with supernatural forces deriving from posthumous 'lives' that intervene violently in a present situation.

\section{Concluding remarks}

Throughout this chapter I have argued that dead bodies are not death matter. On the contrary, corpses transgress natural and supernatural spheres and make the past present in possible futures. This makes the bodies that suffered a 'bad death' in Mexico scary to follow and yet 'good to think with'. But why connect the current excess of violence and the oblivion of some corpses at cemeteries with the necropolitics of Mexico today? After all, there is a significant time difference between a still warm, disfigured corpse and the forgotten bones 'kidnapped' from the cemetery. How can they possibly be part of the same problem? The journey of Beltrán Leyva's corpse does not necessarily demonstrate that there is a social 'life' to his corpse going in that direction. Indeed, the journalists' thrill at how the soldiers dealt with his corpse did not refer to any supernatural force. Yet I suspect this says more about the journalists' disregard for popular Catholicism than about the awe felt among the soldiers and the cartel members involved. Considering the soldiers' reaction and the ethnographic findings of popular Catholicism in gangs associated with this cartel, I have taken the liberty to extend the journalists' speculations and draw attention to what might also be at stake in this renowned case. I suggest that, as a result of Beltrán Leyva's violent death, his corpse is likely to be suspected in Mexico's violent underground economy of confining a restless terrorising force capable of attacking people. If this force can furthermore be used against others, there might be another good reason for a little extra safeguarding of his corpse. Understanding the influence of popular religion gives us here another dimension to all the relevant and, for the author, also significant non-religious reasons discussed at the beginning of the chapter. Vengeance and the strategic spread of terror are certainly also at stake, as well as the 'will to kill', which is at the heart of the force of the sovereigns fighting each other in the drug war. Yet it is when these different 
dimensions of the dead corpses are analysed together that we find another more profound reason why the Mexican military and the Beltrán Leyva and Los Zetas cartels were so preoccupied with this particular corpse. ${ }^{12}$

\section{Notes}

1 From 2002 to 2005 the author worked as an international expert on drug and crime related issues at United Nations Regional Office on Drug and Crime (UNODC) in Mexico City. In 2008 he returned to Mexico City to conduct a full year of ethnographic fieldwork on criminal gangs' religious practices, which resulted in his $\mathrm{PhD}$ dissertation in anthropology in 2011. In 2013 he resumed fieldwork in Mexico City, this time to conduct a family study on conflicts and religious practices.

2 El Reforma, 17 December 2009 (author's translation).

3 El Universal, 19 December 2009 (author's translation).

4 El Reforma, 19 December 2009.

5 ElUniversal.com, 20 December 2009.

6 El Reforma, 21 December 2009 (author's translation).

7 El Universal, 19 January 2010 (author's translation).

8 Spise.com, 17 January 2010.

9 El Reforma, 22 December 2009.

10 El Universal, 22 December 2009 (author's translation).

11 SDPnoticias, 19 December 2009.

12 In October 2012, two months after I had written this chapter, Mexican marines killed another major drug baron, Heriberto Lazcano Lazcano, nicknamed Z-40. His corpse was stolen from the funeral home before he was buried. It appears here that Beltrán Leyva's corpse is not the only 'dangerous corpse' in the Mexican drug war.

\section{References}

Brandes, S., 2006, Skulls to the Living, Bread to the Dead (Oxford: Blackwell).

Fontein, J. and J. Harries, 2009, 'Report of the "Bones Collective" Workshop, 4-5 December 2008: What Lies Beneath: Exploring the Affective Presence and Emotive Materiality of Human Bones', www.san.ed.ac.uk/ research/bones_collective.

Hansen, T. B. and F. Stepputat, 2005, 'Introduction', in T. B. Hansen and F. Stepputat (eds), Sovereign Bodies: Citizens, Migrants, and States in the Postcolonial World, pp. 1-36 (Princeton, NJ: Princeton University Press).

Hertz, R., 1960, Death and the Right Hand, trans. R. Needham and C. Needham (New York: Free Press). 
Kristensen, R., 2011, 'Postponing Death: Saints and Security in Mexico City', unpublished $\mathrm{PhD}$ thesis, University of Copenhagen. Department of Anthropology PhD series 68.

Krmpotich, C., J. Fontein and J. Harries, 2010, 'Preface', Journal of Material Culture 15(4): 371-84. Special Issue: The Substance of Bones: The Emotive Materiality and Affective Presence of Human Remains.

Lomnitz, C., 2005, Death and the Idea of Mexico (New York: Zone Books).

Lydia C., 1975, El Monte (Florida: New House Publishers).

Malvido, E., 2005, 'Crónicas de la Buena Muerte a la Santa Muerte en México', Arqueología Mexicana 13(76): 20-7.

Taussig, M., 1987, Shamanism, Colonialism, and the Wild Man (Chicago: Chicago University Press).

Turner, V., 1967, 'Betwixt and Between', in The Forest of Symbols: Aspects of Ndembu Ritual, pp. 59-92 (Ithaca, NY and London: Cornell University Press).

Verdery, K., 1999, The Political Lives of Dead Bodies: Reburial and Postsocialist Change (New York: Columbia University Press). 